\title{
Döva och gravt \\ hörselskadade ungdomars sociala identitet och självvärdering
}

\section{EGIL ANDERSSON OCH MARIA LAWENIUS}

\begin{abstract}
Artikeln behandlar hur olika uppväxtbetingelser med avseende på oral alternativt teckenspråkig miljö påverkat döva respektive gravt hörselskadade ungdomars sociala identitet, liksom deras självbild, sociala relationer, spräkutveckling och framtidsförhoppningar.
\end{abstract}

Under det senaste halvseklet har man från myndigheternas sida verkat för att integrera personer med funktionshinder i samhället. Detta innebär att man skall kunna leva ett så normalt liv som möjligt i sin egen hemmiljö. Sålunda har statliga och landstingsägda institutioner och specialskolor avvecklats i snabb takt under 1970- och 80-talen. Ett undantag utgör dock specialskolorna för döva.

När det gäller döva personer och personer med grav hörselnedsättning ${ }^{1}$ och dövhet har det inte ansetts lika motiverat med integrering, då man menar att en sådan skulle

Egil Andersson, universitetslektor, och Maria Lawenius, psykolog, är båda fil. dr i pedagogik och har de senaste 20 åren bedrivit forskning vid Institutionen för pedagogik, Göteborgs Universitet. Forskningen har i huvudsak fokuserat handikappproblematik med inriktning på familj och närmiljö. medföra social isolation och ge alltför begränsade möjligheter till kommunikation. Inte minst döva själva har genom sina organisationer verkat för att få bibehålla specialskolorna och betonat vikten av att barn och ungdom tillägnar sig gruppens egen kultur, den s.k. dövkulturen.

Döva är genom teckenspråket och genom en undervisning som varit, och fortfarande är, koncentrerad till några få skolor ofta i internatform, en starkt sammanhållen grupp. Man har sålunda nära och täta kontakter med varandra och kan härigenom utveckla egna umgängesformer och rutiner för sitt beteende och handlande. Genom gemensamma och likartade erfarenheter känner man sig trygg och funktionshindret upplevs

1 Grav hörselnedsättning innebär här hörapparatsanvändare och dövteckenspråksanvändare (Åkerström m.fl., 1995). 
i den teckenspråkiga miljön inte som handikappande. Inom denna miljö kan man då utveckla sin självkänsla och egna identitet.

Barn med hörselnedsättning och även grav sådan undervisas däremot ofta integrerade i den vanliga skolan. En förutsättning för en sådan integrerad undervisning är då att ha tillgång till tekniska hjälpmedel och hörselpedagoger, vilka kan hjälpa eleven och också fungera som handledare för lärarpersonalen. Dessa elever kommunicerar vanligen inte via teckenspråket och har ofta begränsade kontakter med andra hörselskadade elever. De har sålunda inte samma gemensamma »kultur» att falla tillbaka på som segregerade döva eller de hörselskadade elever som undervisas i segregerade skolor har. Det är detta faktum vi har tagit till utgångspunkt i denna studie. Våra huvudfrågeställningar blir därför här :

Med vilken grupp identifierar sig döva / gravt hörselskadade elever, som växer upp i en teckenspråkig miljö?

Med vilken grupp identifierar sig integrerade gravt hörselskadade elever som växer upp i en oral miljö?

Hur påverkas elevernas självbild och självvärdering i teckenspråkig respektive oral miljö?

\section{Teoretiska utgångspunkter för projektet}

Begreppen identitet och självbild är inga enkla begrepp då de är abstrakta och som sådana endast framträder via indikationer. Detta bidrar också till att det finns många teorier kring dessa begrepp och deras relation till de företeelser som indicerar dem.

Vår teoretiska utgångspunkt då undersök- ningen påbörjades var Meads (1934) socialbehaviorism. Enligt denna teori växer självbilden och medvetandet om det egna jaget fram i interaktionen med andra människor. Man får en uppfattning av sig själv genom att iaktta omgivningens reaktioner på en själv (spegling) och genom förmågan att föreställa sig hur andra ser på en själv, dvs. förmågan att inta motpartens perspektiv. På detta sätt växer inte bara självbild och identitet fram, utan även andra viktiga begrepp får på liknande sätt sin mening. Speciellt betydelsefulla blir härvid personer i den nära omgivningen de s. k. signifikanta andra. Genom interaktion med dessa befästs normer och värderingar som är betydelsefulla och som ligger till grund för samhällslivet i stort. Under barnets utveckling internaliseras sålunda dessa värden och kommer att ingå i dess begreppsvärld. Denna kontinuerligt pågående process benämns socialisationsprocessen.

Liksom Mead framhåller också Greenwood (1994) att identiteten är ett socialt fenomen. Han menar vidare att skilda delar av den sociala världen engagerar oss i olika hög grad beroende på $i$ vilken utsträckning man själv omfattar de normer, värden och åtaganden som är förknippade med sådana specifika områden. Dessa värden och åtaganden utgör vad Greenwood kallar våra identitetsprojekt. I den mån man uppfattar att man lyckas respektive misslyckas med dessa projekt ger de också upphov till känslor av t.ex. stolthet eller skam. Identitetsprojekten påverkar också motivationen vad gäller vårt beteende och handlande.

Identitetsprojekt kan emellertid förändras eller ersättas med nya, varvid också den sociala identiteten kan förändras. Genom 
sådana förändringar skapas också möjligheter att utvecklas. Svårigheter och inre konflikter kan dock uppstå om man har förvärvat motstridiga uppsättningar av identitetsprojekt. Under sådana omständigheter uppstår dubbel identitet, som kan avspegla sig genom att individen växlar från den ena identiteten eller rollen till den andra.

Identiteten är också avhängig de konventioner eller lagar som finns fastslagna eller underförstådda inom ett socialt kollektiv. Innehållet i dessa konventioner blir då betydelsefulla. Internalisering av sådana uttalade eller underförstådda överenskommelser leder också till att man får likartade uppsättningar av emotioner och motiv inom ett och samma kollektiv. Genom att urskilja sådana gemensamma uppsättningar kan man differentiera mellan olika sociala kollektiv och identifiera dessa.

Den identitet som man för stunden ger uttryck för kan emellertid vara beroende av den aktuella situationen. Därför är tidsaspekten inte oväsentlig då det gäller att kartlägga identiteter och deras utveckling. Genom att blicka bakåt och se hur individens identitetsprojekt gestaltat sig tidigare, liksom genom att analysera vad individen förväntar sig av framtiden (possible selves enl. Markus och Nurius, 1986) kan sociala identiteter som är mer stabila analyseras. Tidsaspekten har betonats inte minst i Eriksons (1950) psykoanalytiskt orienterade identitetsteori.

Med dessa begrepp menar vi oss nu ha funnit verktyg för en analys och tolkning av de intervjuer som gjorts inom detta projekt, dels med segregerade döva och hörselskadade elever, dels med integrerade hörselskadade elever och normalhörande.

\section{Syfte}

Syftet med föreliggande studie var att undersöka till vilken grupp döva / gravt hörselskadade ungdomar vilka lever i en homogen dövkultur respektive växer upp i oral miljö refererar sig, eller vilken grupp man identifierar sig med, liksom att studera eventuella skillnader i deras självbild och självvärdering. Avsikten var också att kartlägga de funktionshindrades sociala relationer till jämnåriga, samt göra jämförelser med en kontrollgrupp icke-handikappade ungdomar i dessa avseenden.

\section{Metod}

\section{Population}

Undersökningsgrupperna utgjordes totalt av 95 döva och 65 gravt hörselskadade elever, av vilka senare 41 undervisades vid dövskolor och 24 var integrerade i vanlig skolform. Kriterium för grav hörselskada var att vara ordinerad hörapparat ${ }^{2}$. Kontrollgruppen bestod totalt av 488 hörande elever, varav 293 klasskamrater till de integrerade eleverna. Ett bortfall på nio klasser relaterade till integrerade elever uppstod p.g.a. att de integrerade hörselskadade uppfattade det som alltför känsligt att bli uppmärksammade vid en klassundersökning. Elevernas ålder varierade mellan 14-29 år $(\mathrm{M}=16.56$ år, S. D. = 2.06). Samtliga gick i årskurserna $7-10$ på grundskolan alternativt $1-4$ på gymnasieskolan.

2 Ordination av hörapparat sker efter individuell bedömning av såväl hörselnedsättningens art som av den enskilde individens behov. Kriterierna kan i viss mån variera mellan olika bedömare (Tvingstedt, 1993, s 23). 
I intervjuerna deltog 46 segregerade döva och gravt hörselskadade ungdomar. Av dessa elever hade 24 kontinuerligt gått i dövskola, 12 gått i hörselklasser integrerade i vanlig skola och 10 under någon del av sin skolgång varit integrerade i vanliga klasser. I gruppen segregerade elever ingår således såväl helt döva teckenspråkiga elever och gravt hörselskadade elever som huvudsakligen kommunicerar oralt.

Gruppen integrerade gravt hörselskadade elever som intervjuades bestod av $17 \mathrm{el}$ ever från 12 olika sblor i Västsverige representerande såväl grund- som gymnasieskola.

Kontrollgruppen omfattade 16 elever likaledes rekryterade från skolorna i Västsverige.

\section{Undersökningsmoment}

Undersökningen bestod av tre moment:

1. Intervjuer med representanter för huvudgrupperna döva, hörselskadade och normalhörande.

2. Gruppundersökningar bestående av enkäter mätande självvärdering och självbeskrivning, samt ett språkligt test.

3. Sociogram i de integrerade elevernas klassavdelningar. På grund av alltför små klassenheter och individuella program i dövskolorna kunde sociogram ej genomföras i dessa grupper.

\section{Undersökningens genomförande} Intervjuer

Intervjuerna var utformade så att de tillät eleverna komma med egna associationer och var således relativt obundna. Detta för att bredda innehållet och fånga upp för eleven viktiga aspekter på deras uppväxtförhållanden. Avsikten var dock att kartlägga elever- nas tidigare och nuvarande skolförhållanden och upplevelser i samband med skolgången, deras huvudsakliga kommunikationssätt och kontakter såväl hemma som i skolan och på fritiden samt för eleven betydelsefulla vuxna. Härutöver undersöktes upplevelser och erfarenheter vid kontakter med dem som kommunicerar på annat sätt än de själva och svårigheter i samband härmed. Stor uppmärksamhet ägnades också elevernas framtidsplaner såväl kortsiktigt som inför vuxenlivet liksom realismen i yrkesplaner och yrkesförväntningar.

Vad gäller intervjuerna med de segregerade eleverna genomfördes dessa med hjälp av teckenspråkstolk medan vi själva utan tolk kunde kommunicera med de gravt hörselskadade. Samtliga intervjuer har spelats in på kasettband, vilka skrivits ut och senare analyserats.

\section{Analys}

Med utgångspunkt från det teoretiska resonemanget fokuseras i analysen av intervjuerna särskilt fem punkter:

1. Kvalitativa skillnader avseende känslor i samband med hörselhandikappet.

2. Skillnader beträffande motiv för eget handlande.

3. Grupptillhörighet så som denna uttrycks genom innehåll och värderingar i samband med frågan om kommunikationssätt och relationen mellan gruppreferens och ovanstående aspekter på känsla och motiv.

4. Bristande kontinuitet i socialisationsprocessen och analys av svårigheten att utveckla en identitet om betingelserna växlar och identitetsprojekten byts.

5. Självbilden som den avspeglar sig i för- 
hoppningar om framtiden, inte minst avseende yrkesambitioner.

\section{Gruppundersökningen}

Som mått på självvärdering användes Coopersmith (1990) Self-Esteem Inventories (SEI), School Form. Detta undersökningsinstrument består av 50 frågor med två svarsalternativ 'Likt mig' respektive 'Inte likt mig' och relaterade till områdena kamrater, föräldrar, skola och personliga intressen. Härutöver återfinns åtta frågor i en 'lögnskala' som tjänar som index på försvarsmekanismer.

Självbeskrivningen genomfördes med en adjektivlista Jag tycker jag är, av Ouvinen (1984). Denna ger ett generellt mått på elevers självbeskrivning. Den består av 60 adjektiv varav hälften är positiva till sin karaktär och hälften negativa. Eleven har att avgöra vilka adjektiv som stämmer respektive inte stämmer vid en beskrivning av sig själv.

För att undersöka begreppsbildning och språklig förmåga användes Snabb performancetest på intelligens, IQ, även kallat SPIQ (Rydberg och Höghielm, 1974). Testet består av en sida med fyra bilder och tillhörande ordlista omfattande 60 ord. Eleven skall avgöra med vilken bild respektive ord hör samman.

Samtliga mätinstrument är skriftliga och har varit självinstruerande. Möjlighet till förklaringar av instruktioner har funnits då vi själva samlat in materialet och vad gäller de döva eleverna, har teckenspråkstolk alltid varit tillgänglig.

\section{Sociogram}

Sociogrammen avsåg att mäta elevens sociala relationer i skolan. Härvid har eleverna fått namnge de tre klasskamrater de mest är tillsammans med i skolan. Sociogram har upprättats avseende egna val, ömsesidiga val och erhållna val.

\section{Resultat}

\section{Intervjuer}

Vid intervjuerna gavs uttryck för skilda uppfattningar av egen grupptillhörighet eller social identitet. Några sådana kvalitativt skilda identiteter har vid analysen kunnat urskiljas och sättas i samband med olika uppväxtbetingelser. De kan ses som effekter av den socialisationsprocess ungdomarna genomgått i hem och skola.

\section{Segregerade elever}

Döva

\section{Dövidentitet}

Naturligt nog känner de flesta döva elever en klar samhörighet med andra döva och finner också vanligtvis sina vänner inom denna krets. Sådana elever synes ha utvecklat en klar dövidentitet, vilket kommer till uttryck i att man t.ex. ofta säger sig ta avstånd från kommunikation med hörande. Man engagerar sig också starkt för de döva, något som bl.a. visar sig i elevernas framtidsplaner, där man inte sällan hoppas på en utbildning som leder fram till undervisning av döva barn eller omsorg om döva barn och åldringar. I denna grupp möter man ofta elever där dövhet eller hörselnedsättning förekommer bland flera familjemedlemmar, vilket har medfört att teckenspråket blivit det naturliga kommunikationsmedlet inom familjen.

De döva ungdomarna har högt ställda krav på undervisningen och är själva starkt 
motiverade för skolarbetet. Självkänslan är god och självvärderingen hög. Sålunda ser man stora möjligheter att kunna göra sig gällande på arbetsmarknaden och att kunna företa resor till andra länder, detta senare inte minst på grund av teckenspråket, som med vissa modifikationer är internationellt. Detta språk har även andra positiva sidor, då man t.ex. kan kommunicera ljudlöst utan att någon utomstående lyssnar eller utan att störa omgivningen. Man ser också positivt på familjebildning, men partnern skall vara döv eller möjligen teckenspråkstolk. Ett gemensamt språk ses nämligen som mycket väsentligt vid valet av partner.

De elever, vars utsagor här beskrivits i generella ordalag, har haft en kontinuerlig socialisationsprocess i det de under hela sin skoltid gått i specialskola för döva och här kunnat finna för dem betydelsefulla vuxna personer. Många har även tidigt haft kontakter med vad vi kallar "dövkulturen", inom vilken utvecklats egna värderingar och där man under lång tid strävat efter att få teckenspråket erkänt som officiellt språk. Dessa elever synes sålunda klart referera sig till "dövkulturen« och finner gemenskap inom denna krets. Här menar man sig tidigt ha kunnat spegla sig i motparter med likartade erfarenheter.

Ambivalent identitet

Bland de döva återfinns också elever för vilka "dövkulturen« inte direkt varit tillgänglig och där inga familje- eller sociala traditioner avseende funktionshindret finns. Vi har sålunda en grupp elever där teckenspråket inte varit den naturliga kommunikationsformen i hemmet. Ofta har endast modern lärt sig att kommunicera med det döva barnet, medan familjen i övrigt använt oralt språk och eventuella åtbörder.

Hos dessa elever återfinns tecken på en stark känsla av ensamhet. Enligt utsagorna upplever man att hörande undviker dem och man känner sig diskriminerad i förhållande till dessa. Vad gäller identiteten som döv är denna inte lika klart uttalad som hos föregående grupp. Visserligen distanserar man sig från hörande men är inte lika kategorisk som eleverna i tidigare beskrivna grupp, utan kan också se positiva drag speciellt hos dem som visat intresse för att lära sig teckenspråket. Man ser också negativa drag inom dövkulturen som man menar är alltför begränsad till omfånget och vilken man ibland upplever vara något enkelspårig. Vad gäller utbildning har eleverna höga ambitioner, men de säger sig sikta på mer varierande yrken som t. ex. veterinär, idrottslärare och skådespelare, yrken som inte är lika dövinriktade som de som nämnts av elever $\mathrm{i}$ föregående beskrivna grupp.

Det är tveksamt om denna grupp omfattar de normer och värderingar som är utmärkande för dövkulturen, snarare återfinns här en viss ambivalens. Deras socialisationsprocess har heller inte varit lika genuint dövinriktad, så har t.ex. några gått $\mathrm{i}$ blandad förskola med såväl hörande som döva och några av dem bor fortfarande tillsammans med sina hörande familjer och reser dagligen till specialskolan.

\section{Hörselskadade}

Identitet som hörselskadad hörande Bland de segregerade hörselskadade som i många fall tidigare har upplevt integrering $\mathrm{i}$ vanlig klass återfinns en grupp som säger sig redan $\mathrm{i}$ tidiga barnaår ha varit medvetna om 
sitt hörselhandikapp men som kunnat anpassa sig till omständigheterna häromkring. Dessa elever har då ofta haft ett starkt stöd av föräldrar och lärare. Man finner ingen anledning att engagera sig i teckenspråksundervisning då man endast umgås med hörande. Denna grupp av hörselskadade synes klart identifiera sig med hörande om man gör tillägget "hörselskadad hörande».

Flera elever har berättat om hur deras handikappmedvetenhet växte fram i takt med den intellektuella mognaden. Sålunda daterar man den begynnande medvetenheten härom till årskurs 3 medan man anser att denna blir än mer framträdande i årskurserna 6-7.

Även dessa elever uttalar höga yrkesambitioner och siktar på yrken som inte sällan kräver akademisk utbildning. De hyser goda förhoppningar om att också kunna förverkliga sina yrkesplaner. Oftast har dessa nu segregerade elever haft en kontinuerlig socialisationsprocess inom ramen för den vanliga skolan och tillsammans med hörande.

\section{Identitet oklar}

För en annan grupp hörselskadade elever har integrering $i$ vanlig klass inneburit smärtsamma upplevelser, då man menar sig ha blivit mobbad och då man varit generad för sin hörapparat. Ibland har man inte ens velat använda denna utan t. ex. gömt undan den i skolbänken. Många säger sig ha sökt uppträda som hörande, men har då inte sällan gått miste om information med åtföljande komplikationer i kommunikationen. Föräldrarna har också ibland förnekat barnens hörselproblem och betraktat dem som hörande, vilket försvårat barnens insikt om sitt handikapp. Inte heller i skolan har man alltid insett gra- den av elevens hörselproblem. En del av dessa elever säger sig nu efter övergången till den segregerade skolan ha upplevt en viss lättnad, men är ännu inte klara över vilken grupp de skall identifierad sig med utan synes vara ambivalenta med avseende på sin grupptillhörighet. Flera påtalar också de skillnader man upplever mellan dövas kultur och hörandes. Man menar att det finns en stark uppdelning inom den aktuella skolan med avseende på grupptillhörighet. Ambitionerna vad gäller skolgången är varierande i denna grupp liksom självvärderingen.

Utmärkande för dessa med avseende på grupptillhörigheten osäkra elever är att de sällan haft kontinuitet i sin skolgång utan socialisationsprocessen med avseende härpå har varit instabil.

\section{Identitet som normalhörande} Till skillnad från de elever med en ambivalent inställning finns i gruppen hörselskadade också sådana som kategoriskt förnekar sitt handikapp och som säger sig vara helt inriktade på ett vuxenliv i de hörandes värld utan hänsynstagande till funktionshindret. Dessa elever, som förnekar sitt handikapp, ger sken av att ha en hög självvärdering, vilken emellertid tillsammans med förnekandet kan ses som en stark försvarsmekanism mot tillkortakommanden.

\section{Dövidentitet som hörselskadad} Likaväl som det finns döva barn med en helt oral hemmiljö finns det också hörselskadade barn med en teckenspråkig hemmiljö. Dessa elever har också upplevt identitetssvårigheter då de varit integrerade i vanliga klasser, där de haft svårt att anpassa sig då man inte sällan i hemmet internaliserat en

Andersson \& Lawenius - Döva och gravt hörselskadades ungdomars sociala identitet... 
dövkultur. Deras uppväxt har också präglats av en diskontinuitet i socialisationsprocessen, något som man kanske inte varit observant på t.ex. vid skolplaceringen.

\section{Integrerade hörselskadade elever}

Inom gruppen integrerade hörselskadade har vi vid analys av intervjuerna kunnat urskilja två större grupper samt en mindre grupp, vilka markant skiljer sig från varandra med avseende på hur man ser på sitt handikapp och till vilken grupp man refererar sig. Grupperna utmärks av respektive: 1) referens till hörande utan reservation, 2) referens till hörselskadade som en urskiljbar grupp, och 3) referens med dragning mot en dövidentitet.

\section{Identitet som icke-handikappad hörselskadad}

Denna grupp, som omfattar närmare hälften av de intervjuade integrerade hörselskadade eleverna, utmärks av att man betraktar sig som jämlik med sina klasskamrater. Man tillstår visserligen att skolarbetet är krävande och att man får koncentrera sig hårdare än kamraterna under lektionerna och därmed också blir tröttare, men i övrigt menar man att livet inte avviker från de övrigas, och man vill inte heller bli särbehandlad. Flera elever uttrycker klart att de för främlingar inte gärna avslöjar att de är hörselskadade på grund av rädsla för att då betecknas som handikappad och bli betraktad som "dum». Detta är nämligen den föreställning de själva har om omgivningens uppfattning av hörselskadade och döva. Emellertid anser ingen elev $i$ denna grupp att man blivit retad eller mobbad i skolan, i de fall kamraterna känt till funktionshindret.
Dessa elever säger sig vara motiverade för skolarbetet och synes ambitiösa inför sitt yrkesval. De ser heller inga hinder för att deras förhoppningar om en god utbildning, bra arbete och familjeliv skall kunna förverkligas. Efter vad som kan tolkas utifrån deras utsagor är självvärderingen genomgående hög. Med något undantag har dessa elever kontinuerligt varit integrerade i vanliga klasser.

\section{Identitet som handikappad hörselskadad}

Flertalet av eleverna i denna grupp upplever starkt sitt funktionshinder som ett handikapp. Man har uppfattat sig som annorlunda och menar att man ofta har blivit retad i skolan på grund av sitt handikapp. Inte sällan har man också känt sig ensam och isolerad i den vanliga skolmiljön. En orsak kan vara bristande kontinuitet i deras utbildning. Sålunda har man i vissa ämnen haft specialundervisning tillsammans med andra hörselskadade (hörselgrupp), medan man i andra ämnen varit integrerad i vanlig klass. Många av dessa elever önskar nu få sin gymnasieutbildning förlagd till Riksgymnasiet för döva och hörselskadade i Örebro. Ett flertal av eleverna har också med hörselpedagogers hjälp sökt sig till föreningar för hörselskadade ungdomar. Detta torde ha stärkt deras medvetenhet om handikappet och deras identitet som hörselskadade. Hälften av gruppen har utvecklat en god självkänsla och självvärdering och ser fram emot en yrkesutövning inom områdena undervisning och vård av döva och handikappade barn. I dessa fall ser man teckenspråket som en tillgång och vill lära sig detta grundligt. Här finns sålunda exempel på hur man kan omvärdera sitt handikapp och konstruk- 
tivt utnyttja detsamma på ett positivt sätt (positive possible selves). Den andra hälften däremot synes mer pessimistisk och visar inte samma framtidstro. Nagra tycks ha haft det besvärligt under uppväxten och man kan hos dem spåra en isolationstendens och viss uttalad misstro gentemot omvärlden.

\section{Identitet som döv}

Ett par elever identifierar sig med gruppen döva även om de är integrerade i skolan som hörselskadade. De avser också att kommande termin börja i specialskola för döva. Detta deras val av skolform bygger på upplevelsen av att det blir allt svårare att följa undervisningen som integrerad i en vanlig klass och att det lätt uppstår missförstånd vid kommunikationen. Man menar också att man heller inte fått den hjälp man behöver. Även dessa elever har höga yrkesambitioner och vill gärna lära sig teckenspråk för att använda detta i ett framtida yrke. Detta indicerar en god självkänsla och hög självvärdering.

\section{Normalhörande elever}

Intervjuerna med normalhörande elever får ofta en ytligare karaktär än de med hörselskadade och innehållet blir delvis ett annat, eftersom kommunikationsform och härmed förknippade problem inte är aktuella frågor. Vad gäller självvärdering och självbild kan man dock utläsa något med utgångspunkt från elevernas uttryckta ambitioner beträffande skolarbete och framtida förhoppningar avseende yrkesutbildning och arbete.

Givetvis finns det elever med höga ambitioner och vars framtidsförhoppningar omfattar de mest varierande yrken, som t.ex. dataexpert, ekonom, läkare och konstnär.
Detta kan då ses som indikation på en hög självvärdering. Inte sällan har dessa elever prestationsinriktade föräldrar som uppmuntrar höga yrkesambitioner.

Men man ser också exempel på passiva ungdomar, som är skoltrötta och oengagerade och som endast tänker engagera sig $i$ framtida hem och familj och som accepterar de arbeten de kan få. En viss pessimism vad gäller möjligheten till arbete uttalas också, även om man sällan nämner ordet arbetslös $i$ relation till den egna framtiden. Självvärderingen hos dessa elever synes dock ej vara speciellt hög.

Vad gäller de normalhörande elevernas relationer till elever med funktionshinder i allmänhet och hörselhandikappade i synnerhet är deras reaktioner indifferenta och man tror inte att man själv kan påverka de handikappades situation särskilt mycket.

\section{Gruppundersökning}

Självskattning och självbeskrivning

Resultaten av gruppundersökningarna visar att döva enligt Coopersmiths Self-Esteem Inventories har en signifikant lägre självskattning vad gäller allmänna personliga intressen än hörselskadade och normalhörande $(p<.001)$. Även självvärderingen vad gäller sociala relationer är signifikant lägre för döva ( $\mathrm{p}<.02)$. Anmärkningsvärt är emellertid att döva, följda av gruppen segregerade hörselskadade, värderar sig signifikant högre på de skolrelaterade frågorna än vad de hörande eleverna i kontrollgruppen gör $(p<.01)$. Intressant är också att notera att de integrerade hörselskadade har det numeriskt lägsta värdet, dvs. skattar sig lägst i detta avseende.

I lögnskalan uppvisar döva högst poäng,

Andersson \& Lawenius - Döva och gravt hörselskadades ungdomars sociala identitet... 
dvs. har en benägenhet att dölja eller försköna bilden av sig själv, närmast följda av de hörselskadade. Båda grupperna skiljer sig signifikant från de normalhörande $(\mathrm{p}<.01)$.

Vad gäller självbeskrivningarna enligt Ouvinens adjektivlista återfinns inga signifikanta skillnader mellan grupperna.

\section{Kommentar}

Den höga självskattningen beträffande skolrelaterade frågor hos de segregerade eleverna och då speciellt hos de döva, torde kunna ses som en effekt av den individuella undervisningen i smågrupper som specialskolan för döva och gravt hörselskadade kan erbjuda. Alternativt är det fråga om en överskattning som eleverna gör beträffande sina prestationer. De integrerade hörselskadade elevernas mer pessimistiska syn på sin förmåga vad gäller skolprestationer tyder på en mer ogynnsam skolsituation för dessa elever, kanske med alltför begränsad individualiserad undervisning. Dessutom torde också jämförelsen med normalhörande elever i undervisningssammanhang bidra till den låga självvärderingen i detta avseende. På grund av ett alltför litet underlag av elever kan dock inga generella uttalanden göras.

\section{Språklig förståelse och logiskt tänkande}

(SPIQ)

Då svenska är andraspråk för barndomsdöva torde det vara av intresse att undersöka elevernas verbala förståelse av svenska ord. Jämförelser av svaren hos huvudgrupperna döva, hörselskadade och normalhörande visar signifikant lägre värden avseende språklig förståelse av svenska ord hos döva än hos hörselskadade $(p<.0001)$, men den senare gruppen skiljer sig även signifikant från de normalhörande eleverna genom svagare resultat $(\mathrm{p}<.008)$.

\section{Sociogram}

\section{Sociala relationer iskolan}

I klasser med integrerade hörselskadade elever kunde sociogram genomföras avseende kamratrelationer i skolan, medan som tidigare nämnts detta ej var möjligt vid specialskolorna.

Av resultaten framgår att normalhörande elever i genomsnitt erhåller fler val av sina kamrater vad gäller relationer i skolan ( $p<.01)$. De har också fler ömsesidiga val $(\mathrm{p}<.01)$, vilket får tolkas som att relationerna här är djupare och kvalitativt stabilare. Uttryckt på annat sätt - integrerade hörselskadade, som grupp betraktad, har svårare att etablera och upprätthålla kamratrelationer än vad normalhörande elever genomsnittligt har.

\section{Diskussion}

Denna studie har sökt belysa effekter av segregering / integrering av döva och gravt hörselskadade ungdomar från flera perspektiv, dels så som de framträder i de intervjuer som gjorts, dels speglade i elevernas egen självvärdering och självbeskrivning liksom i form av deras språkliga förmåga, och slutligen genom deras kamraters bedömning av sociala relationer (sociogram). Genom olika infallsvinklar söker vi sålunda få en helhetsbild av vad det med avseende på grupptillhörighet, självbild och självvärdering innebär att vara döv och segregerad från kamratskap med hörande elever, respektive vara gravt hörselskadad och då antingen vara 
segregerad från eller integrerad bland hörande elever.

I studien har såväl kvalitativa som kvantitativa data använts. Att på detta sätt kombinera kvalitativa och kvantitativa forskningsmetoder kan ge en djupare förståelse av de skilda gruppernas levnadsvillkor och förhållanden än vad metoderna var för sig gör.

Kvantitativa undersökningar redovisar resultaten i form av statistiskt verifierade gruppmedeltal och signifikanta skillnader mellan grupper.

I kvalitativa undersökningar anges vanligen ej några siffervärden då resultaten bygger på tolkningar av enskilda utsagor. Däremot brukar redovisningen åtföljas av citat och det är med hänvisning till dessa man verifierar tolkningens rimlighet. Citaten har dock i denna framställning uteslutits av hänsyn till elevernas integritet. Anonymitet och sekretess är speciellt känsliga frågor inom dövkulturen, där den inbördes kontakten mellan medlemmarna är stor och man lätt skulle kunna identifiera varandras utsagor.

Då vi inte själva behärskar teckenspråk har en viss osäkerhet förelegat i samband med intervjuerna av de döva eleverna, nämligen den filtrering av elevernas utsagor som är ofrånkomlig då man använder teckenspråkstolk. I dessa fall har vi inte full kontroll över elevernas ursprungliga utsagor eller hur deras emotioner förmedlats, något som kan ha påverkat vår tolkning.

Vid analysen har vi emellertid sökt beskriva kontentan av det innehåll, de motiv och den känsla som intervjuerna mer generellt förmedlar, liksom vi också sökt klarlägga och förstå samband mellan yttre förhållanden och omständigheter relaterade till funktionshindret och den / de självbild(er) som skapas i interaktionen människor emellan under socialisationsprocessen.

I det följande kommer vi att behandla några av dessa samband och deras konsekvenser för utvecklingen av ett hörselhandikappat barns sociala identitet, självbild och självvärdering.

Av grundläggande betydelse för barnet torde vara dess bakgrund med avseende på föräldrarnas erfarenhet av hörselhandikapp. Att födas döv i en familj där föräldrarna är döva innebär för barnet ingen avvikelse från familjens ordinära liv. Barnet kan trots sitt funktionshinder relatera väl till föräldrarna. Föräldrarna vet också vad det innebär att vara döv, och uppfattar sannolikt inte barnet som handikappat, då man har möjligheter att kommunicera i hemmiljön.

Barnets medvetande om funktionshindret blir inte påtagligt förrän det vidgar sin sociala sfär i samband med vistelse på daghem och i lekskola och då skolstarten blir aktuell. För omvärlden är funktionshindret också så uppenbart att några större diskussioner eller motsatta meningar mellan föräldrarna och representanter för olika institutioner eller organisationer inte behöver uppstå beträffande omsorg och skolplacering. Barnet kan sålunda förhållandevis okomplicerat föras in i en dövorienterad värld och internalisera vad vi kallar dövkulturen.

Betydligt mer komplicerat är det för ett dövt barn med hörande föräldrar ${ }^{3}$. Den osäkerhet och ovisshet om barnets funktions-

3 Samma inkongruens och liknande problem torde föreligga då barnet är normalhörande och föräldrarna döva.

Andersson \& Lawenius - Döva och gravt hörselskadades ungdomars sociala identitet... 
hinder, som redan tidigt väcks hos dessa föräldrar, återspeglas givetvis i relationen till barnet. Detta kan intuitivt uppleva att det inte motsvarar föräldrarnas förväntningar och det kan dröja innan föräldrarna dels förstår vad som fattas barnet, dels själva kan och orkar skaffa sig mer kunskap om funktionshindret och dess konsekvenser och om hur man bäst skall kunna hjälpa barnet. Omvärldens krav på föräldrarna kan också upplevas som stora inte minst genom påtryckningar att lära sig teckenspråk. Att finna teckenspråkig miljö och lämplig skolgång kan också vara ett problem för föräldrarna. Allt detta bidrar till otrygghet såväl hos föräldrarna som hos det handikappade barnet.

Smärtsamma frågor och svåra beslut för såväl hörande som döva föräldrar uppstår inte sällan kring de gravt hörselskadade barnen. Det dilemma föräldrarna härvid försätts i är huruvida barnet skall betraktas som dövt eller om tekniska hjälpmedel kan förstärka hörseln så att det kan hänföras till hörande. Inte sällan har föräldrarna en ambivalent inställning härvidlag och de påverkas av divergerande åsikter hos omgivningen. Som grund för deras beslut och avgörande för detta kommer då ofta rent praktiska omständigheter, som t.ex. skolskjuts, tillgång till tolk eller assistenthjälp att vara.

Den vanliga skolans kunskaper och resurser att stödja och hjälpa föräldrarna i deras beslut, liksom att tillgodose de hörselskadade barnens behov synes ofta vara otillräckliga. Av de intervjuer som här gjorts framgår det att barnen ofta omväxlande gått i hörselklass och varit integrerade i vanlig klass, det ena året på en ort eller skola och det andra på en annan. Givetvis torde denna bristande kontinuitet i skolgången påverka bar- nen menligt. En socialisationsprocess där förebilderna ständigt växlar, liksom kontrasterande förebilder i hemmet och i skolan, torde inte befrämja identitetsutvecklingen utan snarare skapa förvirring, eftersom förväntningarna på barnet då blir oförutsägbara och det lätt kan uppleva tillkortakommanden. Effekten av sådan diskontinuitet i socialisationsprocessen blir inte sällan ambivalens beträffande identitet eller vad man kallar dubbel identitet. Sådan identitet åter kan orsaka psykiska störningar hos barnet med djupgående konsekvenser även för vuxenlivet. En parallell kan här dras till andra generationens invandrare i Sverige, där förhållandena i viss mån är likartade (Lawenius, 1990).

Det är således av vikt att söka ge de funktionshindrade barnen en så kontinuerlig och stabil uppväxt som möjligt inte minst då med avseende på kommunikationssätt, då språket har stor betydelse för deras utveckling och sociala gemenskap. För de döva barnens del är idag teckenspråket det naturliga kommunikationsmedlet, medan det talade språket kommer i första hand för hörselskadade barn. För de integrerade gravt hörselskadades del är det emellertid av vikt att också lära sig teckenspråk om skolgången planeras fortsätta i segregerad skola för döva och hörselskadade. Genom att behärska detta språk kan eleven få ett betydligt större kontaktnät bland kamraterna vid specialskolan än eljest.

Vid analysen av intervjuerna har stor vikt lagts vid att studera elevernas framtidsplaner och deras förhoppningar inför framtiden. Vid den teoretiska genomgången hänvisades till individens upplevelse av sina "possible selves." Många av dessa själv är re- 
sultat av tidigare gjorda sociala jämförelser, där individens tankar, känslor och beteende har kontrasterats mot betydelsefulla andras varvid man inte sällan ser dessa personer som förebilder och i positiv mening strävar efter att likna dessa. De positiva möjliga själven tjänar då som motivation för det framtida handlandet. Uppfattas de möjliga själven däremot som svåra att uppnå eller som negativa åtföljs de ofta av nedstämdhet och hämmar då handlandet.

Att finna positiva förebilder liksom att skapa utvecklingsmöjligheter torde vara några av de främsta uppgifterna för föräldrar och lärare, då dessa faktorer har stor betydelse för barnets strävanden och positiva självvärdering. Detta bestyrks i vår studie där vi funnit många exempel på elever som ser framtidsmöjligheter skapade som en följd av det egna funktionshindret, och då inte minst inom yrkesområdena omsorg och undervisning.

Projektet syftade till att besvara tre huvudfrågeställningar, nämligen

1. Med vilken grupp identifierar sig döva / gravt hörselskadade elever, som växer upp i en teckenspråkig miljö?

2. Med vilken grupp identifierar sig integrerade gravt hörselskadade elever som växer upp i en oral miljö?

3. Påverkar de olika uppväxtmiljöerna elevernas självbild och självvärdering?

De generella svaren på fråga ett och två är att de segregerade döva / gravt hörselskadade som växer upp i en teckenspråkig miljö också identifierar sig med gruppen döva. På motsvarande sätt identifierar sig integrerade hörselskadade från en oral miljö företrädesvis med hörande. I båda fallen föreligger en överensstämmelse mellan barnets förmåga att kommunicera och uppväxtmiljöns kommunikationssätt. Är förhållandet det motsatta, dvs. att under uppväxtåren dessa faktorer inte överensstämmer, är man ofta i ungdomsåren ambivalent beträffande sin grupptillhörighet eller sociala identitet, och man växlar mellan att referera sig till döva respektive hörande. I dessa fall påverkas det slutliga valet av social identitet, så som identiteten avspeglar sig i sättet att kommunicera, i stor utsträckning av i vilken miljö man ser möjligheter till social gemenskap och framgång.

Den tredje frågan är vanskligare att besvara, då många för oss okända faktorer bidrar till att forma den enskilde elevens självbild och självvärdering. Med utgångspunkt från elevernas uttalade planer och framtidsförhoppningar synes teckenspråkig respektive oral miljö inte vara det avgörande i detta hänseende, utan fastmer elevernas uppfattning av den egna utvecklingspotentialen och möjligheter att lyckas i framtiden, en uppfattning som dels formas i hemmet, dels i skolmiljön.

Artikeln är skriven inom projektet Döva och gravt hörselskadade ungdomars självbild och sociala realtioner - En jämförelse mellan integrerade och segregerade ungdomar. Detta projekt har stötts av bl.a. Socialvetenskapliga Forskningsrådet. Förstamajblommans Riksförbund och Axel och Margaret Ax:son Johnsons Stiftelse. Resultaten sammanfaller delvis med sådana redovisade inom nämnda projekt.

Andersson \& Lawenius -Döva och gravt hörselskadades ungdomars sociala identitet... 


\section{Referenser}

Andersson, E. (1997). Döva och gravt hörselskadade ungdomars självbild och sociala relationer - En jämförelse mellan integrerade och segregerade ungdomar. Rapport 1. Göteborg: Göteborgs universitet. Inst. för pedagogik.

Coopersmith, S. (1990). Self-Esteem Inventories (SEI). Manual. Adult Form. Palo Alto, CA: Consulting Psychologist Press Inc.

Erikson, E. H.(1950) Childhood \& Society. New York: W. W. Norton \& Company.

Greenwood, J. D. (1994) Realism, Identity and Emotion. Reclaiming Social Psychology. London: Sage Publications Ltd.

Heiling, K. (1993). Döva barns utveckling $i$ ett tidsperspektiv, Kunskapsnivå och sociala processer. Stockholm: Almqvist \& Wiksell International.

Lawenius, M. (1990) Identitetsproblematik hos invandrarungdom.Göteborg: Göteborgs universitet. Inst. för pedagogik.

Lawenius, M. (1997). Döva och gravt hörselskadade ungdomars självbild och sociala relationer. - En jämförelse mellan integrerade och segregerade ungdomar. Rapport 2. Göteborg:
Göteborgs universitet. Inst. för pedagogik. Markus, H. \& Nurius, P. (1986) Possible Selves. American Psychologist Sept., 954-969.

Mead, G. H. (1934). The works of George Herbert Mead. Vol 1. Mind, Self and Society. Chicago: University of Chicago Press.

Ouvinen-Birgerstam, P. (1984). Jag tycker jag ärEn metod för studier av barns och ungdomars självuppfattning. Manual. Stockholm: Psykologiförlaget.

Rydberg, S. \& Höghielm, R. (1974). SPIQSnabbt performancetest på intelligens (IQ) Svenskspråkig version. Stockholm: Psykologiförlaget.

Tvingstedt, A-L. (1993). Sociala betingelser för hörselskadade elever i vanliga klasser. Akad. avh. Lunds universitet. Malmö: Almqvist \& Wiksell International.

Åkerström, M., Eriksson, K., \& Höglund, B. (1995). Dövvärlden i förändring: Om döva och hörselskadades omgivning. Research Reports. Lund: Lund University, Dept. of sociology.

\section{Summary \\ The social identity and self-esteem of deaf and severly hearing-impaired adolescents}

The aim of this study was to investigate with whom the deaf and severely hearingimpaired, living in a homogeneous deaf culture and in an oral environment respectively, identify themselves, and to study any differences in their self image, self-esteem and their social relations towards their peers compared with a control group of non-handicapped adolescents.

The target group consisted of 95 deaf pupils and 65 with severely impaired hearing. Of these 41 pupils studied at special schools for the deaf and 24 pupils were inte- grated into the ordinary school system. The control group consisted of 488 hearing pupils of whom 293 were classmates of the integrated pupils. The age of the pupils ranged from 14 to 29 years.

We found that adolescents living in an absolute sign language milieu and oral environment respectively identify themselves in accordance with their milieu of origin. However, if this is heterogeneous with respect to the way of communication, the adolescents are often ambivalent regarding their own identity. Then the last choice of 
identity is influenced by what they see as their possible selves, that is the judgement of their own development and chances of being successful in the future.

Seen as group, the statistics of the deaf differ statistically significantly from the control pupils in their lower self-esteem ac- cording to Coopersmith's Self Esteem Inventories (SEI). The impairment also influences the pupils' social relations. Thus the integrated hearing-impaired had fewer choices and also fewer mutual choices than their peers at school.

Andersson \& Lawenius - Döva och gravt hörselskadades ungdomars sociala identitet... 